\title{
Sociomuseology as a school of thought and Museologia Social as a practice. How can Museums help to transform the reality of groups under the effect of marginalization?
}

Maria Magdalena $\mathrm{Neu}^{1}$

Sociomuseologia como escola de pensamento e Museologia Social como prática. Como os museus podem ajudar a transformar a realidade de grupos sob o efeito da marginalização?

Introduction

This article aims to draw attention to a new school of thought inside of museology that has been developing with a strong focus in South America for approximately 30 years, and which is still largely unknown to many international scholars: Sociomuseology. In the following, it will be discussed which the innovative features of Sociomuseology (the school of thought) ${ }^{2}$ and especially Social

\footnotetext{
${ }^{1}$ Mestranda em Museologia na ULHT, Iniciou o Bacharelado em Museologia na Universidade de Brasília e graduou na Universidade de Würzburg, Alemanha em Museologia e Etnologia Europeia.

neumariamagdalena@gmail.com

https://orcid.org/0000-0001-7711-1364
}

Submetido Recebido 30-04-2020, aprovado 14.07.2020

${ }^{2}$ Cf. Mário Moutinho: From New museology to Sociomuseology. 24th

General Conference of the International Council of Museums in 2016 Milano 4 july 2016 Joint meeting MINOM/ CAMOC/ ICOFO [online. Opened on 22.08.2020]: 
Museology (one of the Sociomuseological practices) are, and how they can help to improve the lives of the marginalized ${ }^{3}$.

It is important to emphasize that Social Museology (Museologia Social) ${ }^{4}$ was not created by scholars and is only now being appropriated and divulged by universities. The prospects which this development can bring are welcome, if we continue to acknowledge the unique pioneers of the practice, which lie in the work of the people of the Brazilian favelas, quilombos and indigenous communities. We need to also consider that Sociomuseology is not solemnly focused on minorities. Some of the practices, as Ecomuseology for example, work along the guidelines of Sociomuseology with participative processes and interdisciplinarity and are not focused on the weakened parts of society. This article however desires to expose the potential that especially Social Museums have, to actively transform and develop the society ${ }^{5}$ they work with.

To make the introduction to this new paradigm in museology as vivid and insightful as possible we'll present material ${ }^{6}$ from case studies in some of these institutions that call themselves "Museus Sociais" - Social Museums - in Rio de Janeiro. Two of these institutions: the Museu da Favela and the Museu da Maré were chosen because they present different concepts, which neatly illuminate the flexible guidelines that characterize Sociomuseology.

http://network.icom.museum/fileadmin/user_upload/minisites/camoc/PD F/Newsletters/Minom 02.pdf

${ }^{3}$ Meant are the groups that are minorities, not privileged. Immigrants, poor people, people of color, indigenous people, handicapped people, transsexual people, the LGTBQ community... In general, just everyone who does not fit into the majority society.

${ }^{4}$ Museologia Social is a practice of Sociomuseology that emerged in Brazil in its marginalized communities with the desire to develop the territories. You'll find case studies in chapter 3.

${ }^{5}$ Especially the weakened societies.

${ }^{6}$ The material was gathered for my Bachelor Thesis in Germany, at the Julius Maximilians Universität Würzburg from September 2018. 
The result are numerous different approaches which are in line with the great cultural diversity that defines the favela ${ }^{7}$.

To gather data, interviews were done with the directors of the museums and residents alike. Of special interest was the influence of the museums on the latter's day-to-day lives. The interviews were recorded, transcribed and translated to German and now to English. They were not grammatically correct, the language used deviates from the official Portuguese. We intentionally refrained from correcting this to reproduce their way of expression as authentically as possible.

Museologia Social as a practice emerged in South America roughly at the beginning of the new millennium. Social Museums engage with the specific needs of local communities. The discussion about the sociopolitical role of the Museum in a community has been vivid since the second half of the $20^{\text {th }}$ century. ${ }^{8}$ The creation of these

${ }^{7}$ Favelas is the denomination given to Brazilian slums, very financially poor parts of the country. The cultural wealth (samba, capoeira, rap music, diverse dances, diverse religions and syncretisms etc) there is astonishing. The negative circumstances as the police violence and bad access to healthcare, education and other basic rights are equally impressive.

${ }^{8}$ C.f. Cury, M. X. (2014). Museologia-marcos referenciais. Revista Cadernos do Ceom, 18(21), 45-74.

Local Conference of Rio de Janeiro 1958. [Online: http://museudarepublica.museus.gov.br/wp-

content/uploads/2019/05/Livro_seminario_WEB.pdf opened 22.04.2020] page 138

MINOM, M. (2010). Declaration of Quebec-Basic Principles of a New Museology 1984. Cadernos de Sociomuseologia, (38).

LACOUTURE, F. (1984). Declaratoria de Oaxtepec 1984: Ecomuseos, territorio, patrimonio y comunidad. Mesa Redonda de Oaxtepec. Oaxtepec, México. [Online: http://www.ibermuseus.org/wpcontent/uploads/2014/07/declaracao-de-oaxtepec.pdf opened on 22.04.2020]

Nascimento Junior, J., Trampe, A., \& PA, D. S. (2012). Mesa redonda sobre la importancia y el desarrollo de los museos en el mundo contemporáneo: 
institutions can be considered a logical step pertaining to a general paradigm shift within museology, resulting in more social engagement. ${ }^{9}$ Although Social Museums share properties with other museology practices from around the world, like the North American Neighborhood Museums and the French Ecomuseology, they are unique in their emphasis on the responsibility towards the sustainable development of the territory they're in. Latin-America has been a pioneer to materialize these long thought ideas. ${ }^{10}$ Moreover, minorities in the West could also start to open their own social museums to fight the ongoing division and fear of contact between them and the rest of society.

Sociomuseology proposes a shift from "mere" collecting, researching and exhibiting objects; to researching identities, the roots of injustices and offering tools for local populations to become politically and socially aware. ${ }^{11}$ It is not the purpose of this paper to describe the process of emergence of the concept, but to give examples of how it can be realized.

The following milestones in the development of the new museology, which is the beginning of the movement that culminated

Mesa Redonda de Santiago de Chile, 1972. Instituto Brasileiro de MuseusIBRAM, Ministerio do Cultura, Ibermuseos. Brasilia.

${ }^{9}$ C.f. Pereira Leite, Pedro: Sobre Ecomuseus, ecomuseologia e museus comunitários Roteio para programa "Encontros com o Património da TSF". Portugal, 2015. P.2. C.f. Bulat, Elisa. "Como fazer uma Nova Museologia? Análise de uma experiencia do Programa Mais Cultura nas Escolas com o projeto As Tradições da Mata Atlantica na Midia Eletronica e Radiofonica, 2014, Duque de Caxias, Rj. 2016. Brasília. P. 16

${ }^{10}$ Museu de Favela - opened 2009 (Rio de Janeiro, Brazil)

Museu da Maré - opened 2006 (Rio de Janeiro, Brazil)

Centro Cultural Museo y Memória de Neltume - opened 2004 (Valdivia, Los Rios, Chile)

${ }^{11}$ Filgueiras Lima Gabriele, M.C. (2014). Sociomuseologia. Uma reflexão sobre a relação museus e sociedade. [Online: https://periodicos.ufpel.edu.br/ojs2/index.php/expressaextensao/article/v iew/4950/3701 opened: 22.04 .2020$]$. 
in Sociomuseology with its different practices ${ }^{12}$ are of interest: The Round Table of Santiago, Chile, in 1972; The Declaration of Quebec Basic Principles of a New Museology 1984 and the creation of MINOM $^{13}$ (International Movement for a new Museology) in the year of 1985 in Lisbon.

These events highlighted the idea that museums can achieve more than to simply offer knowledge through the presentation of objects - they are now seen as institutions which can and should develop territories and their inherent societies in social, political and economic perspectives.

\section{What does "Social Museology" stand for?}

The institutions that practice Social Museology are usually created by minorities (or groups of interest and collectives) with $^{14}$ their peers ${ }^{15}$, for the purpose of coming to terms with one's own history and identity and to put a bright future in sight. While the traditional museum provides documentation of those for the dominant groups, there is no institution executing this task for the marginalized. This means the Social Museums are creations of people traditionally excluded from public representations. For example, the favela-habitants, people with a low income but a rich and diverse identity not yet embodied in Brazilian museums.

A fitting example, corroborating the lack of representation, is the perverse discourse of the permanent exhibition in the Museu Histórico Nacional. Brazilian history is divided into three periods:

12 as Social Museology, community museology and ecomuseolgy and others ${ }^{13}$ MINOM works as a network between "Favela museums in Brazil, other museums created in disadvantaged neighbourhoods, museums of various social movements, so-called Points of Memory ${ }^{13}$, as well as more traditional museums". ${ }^{13}$ Chagas, Mario/Santos, Paula Assunção Dos/Glas, Tamara: Sociomuseology in Movement: MINOM Rio Declaration. In: Museum International, 2012, Vol.64(1-4). S.99, 100

${ }^{14}$ Note that these museums are not created from one social group for another. They're created by one group with people from the territory itself! ${ }^{15}$ More about this in chapter 3 
"The Portuguese in the World" (1415-1822), "the Construction of the Nation" (1822-1889) and "Citizenship in Development (1889-now) ${ }^{16}$. This official version of Brazil's history starts with the arrival of the Portuguese portrayed as heroes. Little attention is paid to precolonial Brazil and other important historical events such as massacres of indigenous peoples and the history of slavery in Brazil. Although there was a temporary exhibit in the National Museum on the influences of African people on Brazilian cultural identity, such incidents are the rare exception.

This traditional narrative in museums, a white-washed version of history, gets substituted in Social Museums by a version that is composed of different voices. The difference between the official discourse supported by history books and general knowledge, and the often not even registered alternative perspective on the same events is striking. It enriches discourses immensely to include collective memories ${ }^{17}$ in form of interviews and field studies into the collections and gives a much more tangible and human feel to the experience of visiting the museums in question.

We already know that the main target of these institutions is to promote social, economic and especially political development in the territory. Social Museums do research, create collections, document each part of the collection, take the necessary precautions when preparing exhibits, create exhibitions and protect the favelas cultural legacy against oblivion. In Social Museums the collection consists of material and immaterial (knowledge stored in interviews for example) objects which always make a reference to their ${ }^{18}$ experience.

\footnotetext{
${ }^{16}$ Museums of Counternarratives and Resistance, Part 1: Brazilian Museums In Context. Mai 2018. [Online: http://www.rioonwatch.org/?p=43196 opened 22.04.2020].

${ }^{17}$ Halbwachs, Maurice: Das kollektive Gedächtnis. Stuttgart 1967.

${ }^{18}$ The people living in the territory
} 
The focus does not lie on objects, as in traditional museology, but on the people ${ }^{19}$ living in the community. To be able to act, the Social Museum has no need for dedicated buildings, nor does it need professional staff, or any financially valuable exhibits. Mário Chagas, a renowned figure and representative of Social Museology in the world of Science and University, commented on the issue as follows:

"Beginning in the 70s of the 20th century, the classical concept of the museum, which operates with the notion of building, collection and audience, was confronted with new concepts that strictly extended and problematized the concepts cited and worked with the categories of territory (socially practiced), heritage (socially constructed) and community (constructed by bonds of belonging)." 20

Social Museums never focus on profit but on transformation on enabling people to effectively end structural injustice. The marginalized are always exoticized - often even dehumanized - in official narratives offered in schools, universities, politics and museums. In Brazil, the general public associates favela-habitants with violence and danger. Moreover, Brazil is the country with the largest number of inhabitants with African forebears outside of Africa. The institutional racism, manifesting itself in the lack of representation in politics, television, universities, and exclusion from every elitist environment, has deeply felt consequences for their everyday life.

${ }^{19}$ Their past as a group, their present situation and their plans for the future. Their identity and their potential.

${ }^{20}$ Chagas, M. (2013). Educação, museu e patrimônio: tensão, devoração e adjetivação. Revista Eletrônica do Iphan. Dossiê Educação Patrimonial №. P. 3 , Translation by the Author, Original: "A partir dos anos 70 do século XX, o conceito clássico de museu, que opera com as noções de edifício, coleção e público foi confrontado com novos conceitos que, a rigor, ampliavam e problematizavam as noções citadas e operavam com as categorias de território (socialmente praticado), patrimônio (socialmente construído) e comunidade (construída por laços de pertencimento)." 
The motivation that brings these museums to life is to celebrate their cultural heritage, diversity and experience. They can present another perspective of their existence. Simply changing their self-image does not have an effect on their reality, so the museums engage in the task of education, thus offering a thorough overview of the social, economic and political situation.

By finding the roots of injustice in archives, history books and communication with the elders of the community - through interviews for example - it becomes possible to develop solutions for deeply rooted problems. Through collaboration with schools, universities and other local institutions willing to participate, this process of enlightenment is widely reinforced. In 2013, Alice Duarte wrote:

"The consolidation of the social function of the museum presupposes both the abandonment of its traditional isolation from entities such as schools, libraries or local associations, with which it is important to establish partnerships bearing in mind the interest of the populations, and the redefinition of its organization, which is no longer focused on collections but proceeds to focus on themes and stories that make sense to the respective populations." ${ }^{21}$

The inhabitants are not supposed to pay entry-fees because they belong to the museum. They can even be part of the collection in some cases, as will be shown in chapter 3.1. Financially the

21 Duarte, A. (2013). Nova Museologia: pontapés de saída de uma abordagem ainda mais inovadora. Revista eletronica do programa de pos graduacao em museologia e patrimonio - PPG-PMUS Unirio. MAST - vol. 6 no 1. Rio de Janeiro. P. 113, Translation by the author. Original: "A consolidação da função social do museu pressupõe, quer o abandono do seu tradicional isolamento em relação a entidades como escolas, bibliotecas ou associações locais, com as quais importa estabelecer parcerias tendo em mente o interesse das populações, quer a redefinição da sua organização, que deixa de estar centrada nas coleções, para passar a focar-se em temáticas e histórias que façam sentido para as respetivas populações." 
museums will depend on sporadic support from the government and on regular ticket sales to outsiders.

\section{How to realize this concept?}

To be able to function as part of the community the social museum must always articulate and engage the local population. As it is a creation of the community the participation is one of the fundamental brick stones for it to work. The Museum must assume a fundamental role in problem-solving: this is a direct implementation of the statutes stemming from the Round Table of Santiago and found in the Quebec Declaration.

To contextualize the visit in these institutions it is necessary to understand that it is the most superficial of the museums actions. The intention of these museums isn't to only attract tourists. What mobilizes them is the history of the territories, the fights for inclusion and against racism and the sustainable development of the area and society they stand in and are part of. The visits gather financial recourses and validate the museums name in a European perspective. Visits are important but incomparable to the community work that the museums provide - as will be shown in chapter 3.1.2 and 3.2.2.

An exhibition that aims to represent themes, aspects and experiences of a given community can only be created with its citizens and depends on the participation of as many people as possible. To get them enrolled, the museum must network very effectively and make use of any medium of communication imaginable. The main channels are word-of-mouth propaganda, flyers and social media. The following sub-chapters explain how the museum emerges from the people of the territory, what it has to offer, how the territories habitants are engaged in decision-making, curatorship, design and the many other events that are not part of a traditional museum's agenda.

You will be introduced to two of the institutions that are part of Museologia Social and situated favelas of Rio de Janeiro. The museums exhibitions incite and keep up communication between 
themselves, but also between them and the others ${ }^{22}$. As every museum that belongs to this new form of museology, their collections and exhibitions focus on themes that matter to them, their history and identity but also their fights, problems, families, lifestories and much more. Their respective ways of operation could not be more different from each other though:

\subsection{Museu de Favela}

The aim of the Museu de Favela, short MUF, is to show that the favela makes up a decisive and significant part of Rio de Janeiro and its history. It wants to make the territory accessible as a culture attraction. ${ }^{23}$ The history of the creation of favelas, the cultural roots of samba, the culture of north-eastern migrants, black culture, arts and dance are some of the attractions to see. Far from only enlightening the cultural diversity, the museum also treats themes as racism, violence, underage mothers, politics and more.

\subsubsection{Visitation and collection}

At the MUF the whole territory of three favelas is musealized. That implies that Pavão, Pavãozinho and Cantagalo - three communities that are located in between the rich city districts Ipanema, Copacabana and Lagoa - are part of the collection. The area encompasses 12 hectares of area with about 5.300 houses and the 20.000 people living there. Every aspect of their day-to-day lives can form part of the collection; dances, languages, religions, cooking recipes etc. This means that entering the territory is equivalent to entering the museum. ${ }^{24}$

Before visiting, it is important to point out the need for making an appointment with the museums guides. This can be achieved via

22 Outsiders: People from richer parts of the city, foreigners, the government, the military police...

23 C.f. Homepage of the Museu de Favela. [Online: https://www.museudefavela.org/ opened at 22.04.2020]

24 C.f. Homepage of the Museu de Favela. [Online: https://www.museudefavela.org/ opened at 22.04.2020] 
Facebook or the official homepage. It is always also possible to have a translator present. The presence of potentially dangerous third parties in the favelas makes registration imperative before any visit. The government provides the military police, fitted with machine guns and bulletproof protective gear. They can be found at the foot of the hills and will make sure that anyone willing to pass is aware of the dangers ahead. A willingness to continue in spite of possible danger is generally met with great astonishment on their part. Once inside the favela there are young boys spying at every corner, working for the drug dealers, the second party. They are often armed and equipped with mirrors to be able to see in every direction. On the roofs there are more scouts with walkie-talkies registering everyone who gets in. It's a war-like territory. The third force, which I could not spot, but knew they were there, are the militias. They exert power through monopolization of energy, internet and other services. The militias are often composed of ex-policemen who are used to exerting power implicit in social contracts imposed by force. The fourth force, so to say, are the residents themselves. The museum needs to get an "Okay" from everyone to ensure the safety of the visitors.

There are two routes that are open for visits. The "circuito das casas tela", circuit of the canvas houses and the "ecotrilha", circuit of ecology.

At the circuito das casas tela the visitor will be guided through the territory of the three favelas by a local museum guide. Stops are planned at 27 houses that were turned into canvases for mostly graffiti art. The selection of the houses was jointly made by the community, showing their willingness to participate in offering their homes to become touristic attractions. There are, among others, canvases showing the inhabitants' relationship with military police violence, life before there was a reliable water supply, or the lack of electricity. There are also artworks revolving around Afro-Brazilian religions like Candomblé and Umbanda, their music and cultural identity. Another canvas makes romance at a place called Brizola on Cantagalo hill the subject of discussion. 
There might be those who will think: isn't it enough to look at those canvases online? It is not. Because what you cannot see, or better, feel through photographs is the atmosphere: the people and their busy life in the streets and corners, the sounds, the smells of food coming from the many kitchens, the concentration of so much life in so little space. You cannot enter discourse with the people living in the canvas houses proudly presenting their beautifully painted houses, which, before being turned into art, were often not even plastered.

The other route, the "ecotrilha" leads all the way up to the top of the hill where the houses stop, giving way to the rainforest and an impressive panorama view of Rio de Janeiro. On the homepage it says:

"memories of nature before the favela, ecological memories of the favela. There are painted concrete slabs, displays of medicinal plants. The entire circuit was planned collaboratively with the local residents. This educational and memory trail is located in the woods at the top of the hill: from Nova Brasília to Caranguejo (Cantagalo, Pavão and Pavãozinho sub-regions)."25

It also treats the connection of the elders with native plants used as medicine. It is an initiative that puts older generations in contact with school kids who learn about the local plants and their uses. It is one of the projects that makes the local population interact, exchange knowledge and lets them bond in the process. It strengthens the group, reinforces their feeling of identity and provides a platform for education.

These experiences represent the immaterial collection: the feelings, the sights, the noises and smells that make the visit of this museum so different to traditional institutions. Apart from that, the visitors are invited into the many little stores and restaurants and

\footnotetext{
${ }^{25}$ Homepage of the Museum: [Online: https://www.museudefavela.org/visitacao-integrada opened at 22.04.2020]
} 
thus have the chance to support the local economy. All profits from ticket sales are reinvested into the museum, which means they are exclusively used to help the development of the territory. The routes represent the permanent exhibitions of the museum.

Collecting, documenting and protecting immaterial culture via interviews is a very common practice in social museums. The format of banners for temporary and traveling exhibitions is used at the MUF because it makes it easy to relocate these collections to other institutions like universities, other museums or schools. They are also cheap to make, which is always a factor to keep in mind with the tight budgets they operate on.

\subsubsection{Offerings for the local community}

The most important factor that enlivens these institutions are the activities that are organized there. At the MUF these activities take place at the administrative ${ }^{26}$ building or in another building called Brizola. The museum offers many different activities revolving around subjects like racism, black culture, history, creating selfawareness, but also ballet or English classes to the locals. The locals do not pay for these courses. Antonia Ferreira Soares, one of the directors of the Museum, had the following to say:

"We also do workshops with the topics Quilombolas" which is practically a matter of being black, like the Maracatu ${ }^{28}$, the Reggae, the Maculelê dance, the Capoeira and all these things here in the museum. We also had extremes like Ballet and English. We always try to organize

\footnotetext{
${ }^{26}$ In the administrative building there is a classroom, a computer room (where all the mediatic collection is stored), a conference room and the temporary collections (Banners) are stored pretty much everywhere they fit. 27 Quilombos are communities that developed as Brazil was still a Portuguese colony. Slaves that were able to escape, indigenous people who were expelled from their tribe and had no belonging and people who had problems with the law and were able to escape would start new communities, mostly in the woods. Quilombolas are mostly black people but there can be other ethnicities too.

${ }^{28}$ Maracatu is a Brazilian music style.
} 
things that can awaken people in their everyday lives, be they black, be they white, be they a little better in their [financial] situation or be they very poor. Sometimes we have people who are very poor in the financial sense. This thing with pregnancy in youth, we try to treat all that, you know?"29

The interview continued:

"For children and teenagers there are also workshops that deal with the topic of 'negritude' [blackness]. In a sense where the child learns to accept his color, to accept his hair, and not to ask why is this dude white and I am black? Why do I have this color and that person has a different one, you understand?"30

${ }^{29}$ Interview with Antonia Ferreira Soares at 27.03.2018. Translated by the author. Original: "com as criancas, normalmente a gente desenvolve oficinas tambem voltadas justamente pra essa questão do quilombola que é né uma coisa basicamente do negro ne, que é o maracatu, é o reggae, né, é o maculele, a capoeira, né todas essas coisas assim a gente sempre desenvolve essas coisas aqui tambem no museu e já tivemos ate o extremo de ter aula de ballet, e de ingles, ne. Então a gente ta sempre procurando desenvolver coisas que possam despertar as pessoas pro dia a dia da vida mesmo ne, seja ela negra, seja ela branca, seja ela melhorzinha de situação ou seja ela muito pobre né porque a gente tem pessoas que as vezes são ainda muito pobres no sentido financeiro ne, essa questão da gravidez na adolescencia, tudo isso a gente procura trabalhar entendeu."

${ }^{30}$ Interview with Antonia Ferreira Soares at 27.03.2018. Translated by the author. Original: "com as criancas, normalmente a gente desenvolve oficinas tambem voltadas justamente pra essa questão do quilombola que é né uma coisa basicamente do negro ne, que é o maracatu, é o reggae, né, é o maculele, a capoeira, né todas essas coisas assim a gente sempre desenvolve essas coisas aqui tambem no museu e já tivemos ate o extremo de ter aula de ballet, e de ingles, ne. Então a gente ta sempre procurando desenvolver coisas que possam despertar as pessoas pro dia a dia da vida mesmo ne, seja ela negra, seja ela branca, seja ela melhorzinha de situação ou seja ela muito pobre né porque a gente tem pessoas que as vezes são ainda muito pobres no sentido financeiro ne, essa questão da gravidez na adolescencia, tudo isso a gente procura trabalhar entendeu." 
These activities are immensely important for the young. Antonia continues:

"From the moment we work with the 'favelado' [favela-habitant as a theme], we work with the whole spectrum of racism. Because sometimes the person hears a little joke about the color of their skin, or people who don't accept their color [sic!]... Also this project 'Afrobetizar' ${ }^{31}$, is a project in which we especially work with children and teenagers who work on the topic of their identity." 32

Further: "So, we try to develop actions [sic!] for and with the locals, where he [sic!] participates, brings suggestions, gives incentives." 33

These courses, activities and lectures are very important. Favela habitants are underestimated wherever they go. Brazil is a racist country, where the white population clings to its power and privilege, while black and indigenous people are belittled and ostracized. The shift in perspective, learning about the rich African, Afro-Brazilian, indigenous and favela culture (and the whole spectrum of syncretism between) with their dances, languages, religions - general manifold identities - empowers the favela inhabitants to feel pride for their heritage and ancestry. Also, it sheds light on the roots of the injustice they are born into. The ultimate goal is to enable them to defend themselves against institutional racism and to make their voices heard as a political entity.

\footnotetext{
${ }^{31}$ Word game made out of Alphabetize and Africa.

${ }^{32}$ Interview with Antonia Ferreira Soares at 27.03.2018. Translated by the author. Original: „do momento que a gente trabalha do favelado, ne, a gente trabalha toda essa questão do racismo, ne, porque as vezes a pessoa é ouve uma piadinha sobre a cor que ela tem, ou tem pessoas que não aceitam a cor que tem, tendeu, inclusive esse projeto do afrobetizar que nós temos aqui ele é um projeto desenvolvido com criancas e adolescentes."

33 Ibid. Translated by the Autor: Original: "Então a gente procura desenvolver ações realmente assim sempre voltadas para com para o morador com o morador participando, sugerindo, incentivando, assim."
} 
As an outsider interested in offering any sort of education, workshop or experience with the aim to help the community, you can always contact the museum and they will offer you a space and an audience. In this way the museum carries out one of its main functions: to foster communication between the many heterogenous groups of society.

\subsection{Museu da Maré}

The Museu da Maré, short MM, has had the purpose from the beginning to improve the everyday life in an area that includes 17 favelas, which together are called Complexo da Maré, complex of the tide. At this moment there are 140.000 people estimated to be living there. ${ }^{34}$

The location is particularly interesting because there was no solid ground there until the 70s. People were living in houses on stilts before the territory was reclaimed. These landfills also brought the possibility of constructing the federal university right beside the complex.

The Complexo da Maré is situated between two highways and the "isle of the university". The proximity to the university facilitated active involvement and political activism on parts of the favelas' inhabitants culminating in the creation of the CEASM $^{35}$ (Centro de

${ }^{34}$ Data received via Whatsapp by Claudia Rose, one of the Museums directors, at the 9.8.2019.

${ }^{35}$ Maré's research and solidarity centre. One could also mention the first initiative of the Mare as a unit - a newspaper that was created in the 80's: "União da Maré". It had a mediative character between the government and the inhabitants of the Maré. Moreover, it had the intention of forming an identity for all the 12 favelas since the 1980s (when the first publications took place). C.f. Chagas, V. (2009). Por que é cidadão o jornalista cidadão? História das mídias e jornalismo cidadão de base comunitária no Complexo da Maré. In: Universidade Lusófona (Ed): Cadernos De Sociomuseologia № 40. Portugal, 2011. P. $65 \& 66$ 
Estudos e Ações Solidárias da Maré) in $1997 .{ }^{36}$ Some of the people engaged in political activism got together to plan a systematic intervention in the everyday life and reality of the territory. ${ }^{37}$ The self-proclaimed mission of this center has always been "to facilitate the access of the Favela residents to cultural and economic resources through mechanisms of confirmation of their rights (legal confirmation)". ${ }^{38}$ Carlos, Cláudia and Marilene, the three museum directors which were interviewed, are also founders of the CEASM.

The Museu da Maré is a product of coincidence. It was not planned but came into existence as a byproduct of actions taken by the CEASM in the process of researching local collective memory. On the official homepage you can read the following:

"In the case of Maré, the interest in remembrance developed in the wake of a community video project carried out by young inhabitants, who, in an initiative to record the speech of the eldest, came across a story they weren't aware of. From these oral testimonies emerged images of a memory that answered old questions of these young people. [...] This is how the seed of the collective process of history construction was planted. During their search for their own identities, these adolescents immersed into research of local history, which did not limit itself to oral testimonies, but soon

${ }^{36}$ C.f. Interview conducted with Cláudia Rose at the Museu da Maré. 21.03.2018.

${ }^{37}$ Silva, C. R. R. D. (2007). Maré: a invenção de um bairro (Doctoral dissertation). [Online:

http://bibliotecadigital.fgv.br/dspace/bitstream/handle/10438/2122/CPD OC2006ClaudiaRoseRibeirodaSilva.pdf? sequence $=1 \&$ isAllowed $=y$ opened 22.04.2020]

${ }^{38}$ Silva, C. R. R. D. (2007). Maré: a invenção de um bairro (Doctoral dissertation). [Online:

http://bibliotecadigital.fgv.br/dspace/bitstream/handle/10438/2122/CPD OC2006ClaudiaRoseRibeirodaSilva. pdf? sequence=1\&isAllowed=yopened 22.04.2020]

P. 181. Translation by the author. Original: "potencializar o acesso de moradores de favelas e bairros populares aos bens sociais, culturais e econômicos por meio de mecanismos de afirmação de direitos" 
encompassed other forms of documentation, mainly through a sort of archaeological process of image analysis, because their principal aim had been to make a video which told the story of the location." ${ }^{39}$

\subsubsection{Visitation and collection}

When you visit the exhibition of the Museu da Maré, you'll be entering a complex of buildings, different to the MUF, where you walk through the territory. But does that mean that the Museum functions exclusively inside that building? Absolutely not! Again, the exhibitions are the most superficial part of the museums actions. There are many more actions that take place outside of these buildings that make the MM successful in their purpose of transforming the territory as will be shown in the next chapter.

The collection and exhibition are guarded in the main building and consist of objects donated by the residents, chosen to be representative of their identity. Unlike in the Museu de Favela, there is a substantial material collection here. The items are used to contextualize the stories told by the inhabitants. For example, the

39 No Author. Depoimentos. Da Memória ao Museu. [Online: http://www.museudamare.org.br/index.php?option=com content\&view= article\&id=99\&Itemid=57 opened 22.04.2020] Translation by the author. Original „No caso da Maré o desejo de memória se manifestou a partir da tomada de consciência de jovens moradores, que ao desenvolverem uma experiência de vídeo comunitário, numa proposta de registrar a fala dos mais velhos, se viram surpreendidos por uma história que não conheciam. Desses depoimentos orais surgiram quadros de memória que respondiam a antigos questionamentos desses jovens. [...] Surgia assim a semente de um processo de construção coletiva da história. $\mathrm{Na}$ busca de sua própria identidade, estes jovens mergulharam num processo de pesquisa sobre a história local, que já não se limitava apenas ao depoimento oral, mas avançava em outras formas de registro documental, principalmente num processo quase arqueológico de identificação de imagens, já que o objetivo principal era o de realização de um vídeo que contasse a história do lugar." 
"Rola-Rola" 40 is such an object which represents the struggle of transporting water in the past. It is also interesting that the museum objects continue to be used when there is need to ${ }^{41}$.

The permanent exhibition of the Museu da Maré is divided into twelve parts. "The twelve times of Maré" is an analogy to the twelve hours of the day. It is a cycle and therefore differs to the western linear way of planning exhibitions. ${ }^{42}$ All the exhibited objects were donated by the people of the community. The names of the 12 times are: Time of water, time of migration, time of home, time of work, time of resistance, time of festivity, time of market, time of everyday life, time of faith, time of children, time of fear and time of the future. Not every time of the Maré will be described. The following were selected to represent their way of practicing Social Museology.

The third Time, Time of Home, is a house on stilts. The wooden house is blue, and you can walk through the stilts beneath it. Following the stairs on the side you can enter the house. Inside you'll see: a single bed, a little kitchen, a little locker and many small everyday things. The metal comb on the gas stove used to straighten the Afro-Brazilian hair symbolizes the micro-aggressions that are culturally imposed on black people in Brazil. Two visitors the author met there told they remember burning their scalp with these. This was the kind of housing used by the Maré-people until 1980, when the landfills came. The landfills have led to better sanitation, therefore less health-issues, and increased security, since there are no more child-deaths due to falling between the wooden floors.

\footnotetext{
${ }^{40}$ The Rola Rola is a barrel around which a car tyre is put in order to be able to roll it better. A metal handle is attached to the sides of the barrel to make it easier to pull the barrel. In the past, water was transported in these objects before there was running water. At the visit of the museum, you are able to see this object, touch it and talk about it with your guide.

${ }^{41}$ If someone were to need the Rola-Rola for example, the museum would lend it to them.

${ }^{42}$ C.f. Patel, Gitanjali: Museums of Counternarratives and Resistance, Part 2: A New Kind of Museum \#MuseumWeek2018. Mai 2018. [Online: http://www.rioonwatch.org/?p=43330 opened 22.04.2020]
} 
Times four and five, time of work and time of resistance, are jointly presented. Here the constant fight against eviction is portrayed. Work and resistance are addressed together because without either of them Maré would not exist. The highlight is an audio-recorder, which was used by the habitants to record speeches of politicians to be spread in the community.

Time nine is the time of faith and shows the great variety of religions. From Catholicism, over Buddhism to indigenous beliefs, every religion has a little representative here. However, the AfroBrazilian religions like Candomblé and Umbanda are prioritized because they have always been endangered by prosecution especially through committed evangelic Christians. Their houses of religion, the so called terreiros, are still frequently burned down and destroyed because they are believed to worship the devil.

The $11^{\text {th }}$ time is the time of fear. The greatest fears of the inhabitants are: illness, violence, loneliness and unemployment. But prior to the landfills, other fears were recurrent: "hunger, storms, high tides during the night, rats that invaded homes and attacked children and eviction." ${ }^{43}$ Today there is the fear of violence, stray bullets, drug trafficking, police operations and senseless death. ${ }^{44}$ On the wall are plaster casts, made by young Maré-habitants in the context of an activity offered by the museum, of bullet holes found on the streets.

The time of future is where temporal exhibitions find their place. Fear does not have the last say here, therefore the last part of the museum deals with the time to come. The conviction that the future can only be different, if one gets aware of the past and the present, leads to the regular redesign of this part of the exhibition.

\subsubsection{Offerings for the local community}

${ }^{43}$ C.f. The Maré Museum. Come and learn our history. Permanent Exhibit. The Times Of Maré. Fight, Restistance, Memory. Texts: Claudia Rose Ribeiro da Silva. Translations: Katie de Araujo. Rio de Janeiro, 2017. P. 11 ${ }^{44} \mathrm{Ibid}$. 
While the museum analyses, explores and exhibits the history and identity of the territory, it simultaneously achieves something even more significant: it stimulates people to be proud of their identity, their history and values the perils of their ancestors which made their home what it is now. Marilene, one of the directors reflects:

"Even I used to be ashamed before I came into contact with CEASM, you see, before all that I was a person who was ashamed to live in Maré. I didn't say I lived in Maré, I always said I live in Bom Sucesso ${ }^{45}$. You know? That has changed. Where do you live? I live in Maré! They started to appreciate it. You understand the esteem? What is very important, I think, is that you must always value the place where you live. The earth you have always stepped on, you know, today I value everything I used to do in Maré, every water canister I put on my head. I sold water, there was no water in Maré, so I went with a friend and collected some, carried it to fill boxes and cans with water. It was money I earned to help at home, to help my mother, you know? So, I sold water, and if you ask me what the social function of the museum is, it's the appreciation, you know?"46

\footnotetext{
${ }^{45}$ Neighboring community, a little bit wealthier.

${ }^{46}$ Interview conducted with Marilene Nunes at the 21.03.2018. Translation by the author. Original: „porque eu mesma antigamente, antes deu conhecer a ong CEASM, entendeu, antes de tudo era uma pessoa que eu tinha vergonha de morar na Maré. Eu não dizia que eu morava na Maré, eu dizia que eu morava em Bom Sucesso. Sabia. Mudaram. mora onde? Moro na Maré! Passaram a valorizar é a valorização entendeu. Que é muito importante eu acho que você tem que valorizar sempre o lugar onde você mora. A terra onde você sempre pisou sabe eu valorizo hoje em dia assim cada coisa que eu fazia na mare, cada lata d'agua que eu botava na minha cabeca. Eu vendia água, não tinha agua na Maré então eu saía com um amigo meu catava, carregava a àgua pra encher caixas d'agua e latões de agua. Era um dinheiro que eu ganhava pra ajudar dentro da minha casa. Pra ajudar a minha mãe sabia. Então eu vendia água então essa função social que você pergunta aí é a valorização sabia."
} 
The shame related to her own identity and origin that Marilene felt is a common phenomenon. The majority society's prejudiced view of favela inhabitants is a weight that children and adults are used to carry from early on in their lives. For most of them it is unclear that their inferiority only has validity in the discourse controlled by the dominant classes. Thus, the raising of awareness and identity building can mean salvation for many young people who, without the museum, would live their lives in the belief to be doomed second class citizens.

The exhibition is permanent, which does not mean that it is static. Changes are constantly made with participation of the local population and objects are added or removed from the exhibition rooms. In order to be able to make changes in society, it must logically be integrated into the processes. Cássia Rodrigues writes:

"For this, the museum counts on the participation of [local] society in terms of administration and operation. This participation consists in frequent part-taking in the activities offered, donation of objects for the collection, organization of exhibitions and debates as well as taking important decisions concerning the institution". ${ }^{47}$

Thus, the planning of the museum is interdisciplinary and inclusive as it can only function with the help of the museum's employees and the local social groups. ${ }^{48}$

Carlinhos ${ }^{49}$ explained in an interview how this is achieved:

"When we intend to make a change in the museum, we call in a meeting with cultural leaders, we invite people, then

\footnotetext{
${ }^{47}$ Silva, C. R. R. (2012). Caminhos para a sustentabilidade dos museus na cidade. Um estudo de caso na RMRJ. Niteroi. P.194. Translation by the author. Original: "Por isso, o museu conta com a participação da comunidade na sua gestão e no seu funcionamento. Essa participação se dá desde a frequência às atividades, doações de peças para o acervo, montagens de exposições até o debate e tomada de decisões importantes para a instituição"

${ }^{48}$ C.f. Ibid.

${ }^{49}$ Antonio Carlos Pinto Vieira.
} 
we introduce a bit of the projects and ask everybody to give their opinion, to contribute, be it ideas, be it with objects [...] What change the museum should make, what objects should be exhibited [...] On the other hand, if something happens in society that concerns them, then the museum also makes a change in its exhibition [...] for example the situation with the murder of Marielle. ${ }^{50}$ The people are very involved with the perspective to do something about the memory, and we're thinking about how we're going to communicate that and try to keep Marielle's memory alive through a museum action." ${ }^{51}$

In the interview with Carlinhos it became clear that museum narratives are a place of competition. When you provide an

\footnotetext{
${ }^{50}$ The murder of Marielle Franco, a city councilor in Rio de Janeiro who was born and raised in Maré, fought her way to university in CEASM's PréVestibular, and worked her way up to the position of a city councilor, has become a headline all over the world. Two days before her murder, she had reported the violence by the police in a "pacifying intervention" in a favela on Facebook. The weapon that killed her originates from the police.

C.f. https://en.wikipedia.org/wiki/Marielle_Franco, C.f. Ramalho, Sérgio. WHO KILLED MARIELLE FRANCO? AN EX-RIO DE JANEIRO COP WITH TIES TO ORGANIZED CRIME, SAY SIX WITNESSES IN POLICE REPORT. The intercept. 18.01.2019. [Online: https://theintercept.com/2019/01/17/mariellefranco-brazil-assassination-suspect opened 22.04.2020]

${ }^{51}$ Interview conducted with Antonio Carlos Pinto Vieira at the 23.03.2018. Translation by the author. Original: "Quando a gente vai fazer uma mudanca no museu a gente faz uma reunião e convida liderancas, convida pessoas, e ai a gente expoe um pouco o projeto e pede pra que eles opinem, pra que eles participem tambem, seja com ideias, seja com objetos, que a gente expoe tambem um pouco essa[...] que tempos a gente pode ta trabalhando no museu[...] né [...] que mudanca essa exposição pode ter, que objetos a gente pode trazer e expor. [...] Por outro lado, quando você tem algum, alguma coisa que acontece na comunidade, que mexe com a comunidade, o museu então ele, ele faz um movimento tambem com a sua exposição,. por exemplo essa situação, esse assassinato da marielle, a gente ta muito envolvido agora na perspectiva de fazer algum movimento de memória ne, como que a gente vai comunicar e tentar manter viva essa memória da Marielle atraves de uma ação do museu ne."
} 
alternative discourse, the justification of the official discourse is questioned.

The museum also opens its doors for meetings of political activist groups like the "black youth", the LGBTQ community and whoever needs a place for debates and meetings and has the development of the region in mind.

Since the museum promotes critical reflections on social and political paradigms, for example through debates, it also promotes universal understanding and stimulates change in society. This is how most of the people interviewed by Cássia Rodrigues perceived it. ${ }^{52}$

All projects, activities and actions revolve around the historical and cultural identity of Maré and aim to strengthen the communal links between the residents. ${ }^{53}$ Cássia Rodrigues da Silva summarizes that the activities and projects that usually take place are:

"cultural and educational activities planned with and/or for the community; service/support for researchers; activities outside the museum; research, conservation and documentation of the collection; research on the intangible and material local cultural heritage; temporary or short time exhibitions, permanent or longterm exhibitions and travelling exhibitions; guided visits; academic events; courses and workshops; musical, theatrical and dance performances; cinema and film screenings; markets and sale of products." ${ }^{\text {}} 5$

${ }^{52}$ C.f. Silva, C. R. R. (2012). Caminhos para a sustentabilidade dos museus na cidade. Um estudo de caso na RMRJ. Niteroi. P. 209.

53 Ibid. P.182

54 Ibid. P.194, 195. Translation by the author. Original: "ações culturais, educativas e planejadas com e/ou para a comunidade; atendimento a pesquisadores; atividades extramuros; pesquisa, conservação e documentação de acervo; pesquisas de patrimônio imaterial e material local; exposições temporárias ou de curta duração, permanentes ou de longa duração e itinerantes; visitas guiadas e mediadas; eventos, conferências e palestras; eventos acadêmicos; cursos e oficinas; espetáculos musicais, teatrais e de dança; cinemas e projeções de vídeos; feiras e vendas de produtos." 
Computer courses, language courses, graffiti and other arts programs are also offered free of charge for the locals there.

4. How the Museum can be an instrument of sociopolitical engagement of the excluded.

Finally, after observing how these museums work and what they aim for, it is interesting to recapitulate why they exist in this manner. When people are born into a marginalized context and do not know why their sociopolitical environment is the way it is, the perspective for possible change often gets lost. The flame that sparks in some people that start to understand where all these problems come from ignites a fire in the community. In this case, as they learn how little can be changed as long as they have no representation in official institutions like universities, museums and the government, they will be moved to take matters into their own hands and start creating their own spaces where their narratives matter.

We perceive this paradigm shift as a response to the way history has been narrated in traditional education institutions like schools, universities and museums - not only in Brazil but on a global scale. The shift from official history to collective memory in museum exhibitions is fundamentally deconstructive and provides a vehicle for an exchange of information that is flexible and open for discussion. The museum both receives from and gives to the community it represents.

Social Museology distinguishes itself from other museology practices particularly through the fact that it does not patronizingly assume the role to assess the value of the discourses it presents. It tries to link and incorporate those voices which have been silenced for too long and can provide a lot of information on topics that the elite ignores; among other things, collective memory of numerous ethnic groups, knowledge about nature, the roots of which reach back to the narratives conveyed by Indigenous and African ancestors. Selected are topics that are relevant to the development of all facets of said society, treating issues that very often are related to identity, collective memory versus official history. The institutions also 
actively engage in problem solving of punctual situations that may surge. The Museus Sociais no longer restrict themselves "to traditional tasks such as collecting, preserving, researching and exhibiting" 55 , but focus on their social responsibility, working with the cultural heritage which has been researched, collected, documented, conserved and finally exhibited. It is an extended concept of museology, which does incorporate traditional characteristics of a museum to an extent.

A social museum could fulfill the function of a mediation entity. The museum can present as a space for knowledge exchange ${ }^{56}$. A place of encounter, discussion and learning. Political and alive. Museums can approximate groups in society that normally have no platform to interact on the same level.

The end of the seclusion of the museum in relation to other institutions like libraries, schools and universities and the marginalized groups that exist in every society is an important step. Operating with locals when deciding which stories to tell in the museum (and from which perspective) is fundamental when aiming at a representative narrative. As museums are public organs, their mission is to serve society. Patrimony is researched, collected, taken care of, documented and finally communicated through exhibitions. Including immaterial culture is a step forward to decolonize ${ }^{57}$ the museum-institution because most of the marginalized groups do not have the financial resources to have their patrimony materialized in expensive monuments like the western majority society has. The acknowledgement about potential social functions of the museum which can help a group to develop on so many levels is an immense accomplishment.

\footnotetext{
${ }^{55}$ C.f. Ganslmayr, Herbert: Die Bewegung "Neue Museologie". In: Hermann Auer (Ed.) Museologie. Neue Wege - Neue Ziele. München 1988. P.79 ${ }^{56}$ C.f Freire, P. (2005). Pedagogia da autonomia: saberes necessários à prática educativa. São Paulo: Paz e Terra, 1996. Coleção leitura, 21.

${ }^{57}$ C.f Pereira, M. R. N. (2018). Museologia decolonial: os pontos de memória e a insurgência do fazer museal. Lisboa (doctoral dissertation)
} 
This paper is an attempt to trigger thoughts about the role of the museum in society, presenting examples of how changes can affect the reality of people slowly but steadily. We have seen such example at Museu da Maré, where people effectively feel pride to be part of the community, a fact that they were ashamed of before. It was shown how important it is to deal with one's own history, one's own ancestors, and to think about the future with the community.

Social Museology and other Sociomuseological practices can help to tear down invisible walls between groups, it can function as a communication organ, as an institution that supports the society it aims to serve and can help it develop. The fundamental key to this is to educate people about the workings of their environment and thus provoke critical thought leading to actual change

\section{References}

BULAT, E. (2014). Como fazer uma Nova Museologia? Análise de uma experiencia do Programa Mais Cultura nas Escolas com o projeto As Tradições da Mata Atlantica na Midia Eletronica e Radiofonica, 2014, Duque de Caxias, Rj. Brasília

CHAGAS, M., Santos, P. A., Glas, T. (2012). Sociomuseology in Movement: MINOM Rio Declaration. Museum International, Vol.64 (1-4). P.99-106

CHAGAS, V. (2009). Por que é cidadão o jornalista cidadão? História das mídias e jornalismo cidadão de base comunitária no Complexo da Maré.

CHAGAS, M. (2013). Educação, museu e patrimônio: tensão, devoração e adjetivação. Revista Eletrônica do Iphan. Dossiê Educação Patrimonial №.

CURY, M. X. (2014). Museologia-marcos referenciais. Revista Cadernos do Ceom, 18(21), 45-74.

DUARTE, A. (2013). Nova Museologia: pontapés de saída de uma abordagem ainda mais inovadora. Revista eletronica do programa de pos graduacao em museologia e patrimonio PPG-PMUS Unirio. MAST - vol. 6 no 1. Rio de Janeiro. 
FILGUEIRAS Lima Gabriele, M.C. (2014). Sociomuseologia. Uma reflexão sobre a relação museus e sociedade. [Online: https://periodicos.ufpel.edu.br/ojs2/index.php/expressaexte nsao/article/view/4950/3701 opened: 22.04 .2020$]$.

FREIRE, P. (2005). Pedagogia da autonomia: saberes necessários à prática educativa. São Paulo: Paz e Terra, 1996. Coleção leitura, 21.

GANSLMAYR, H. (1988). Die Bewegung "Neue Museologie”. In: Hermann, A. (Org.). Museologie. Neue Wege - Neue Ziele. München. S.80-88

HALBWACHS, M. (1950). La mémoire collective. Paris

MARIA, A. (2018). Museu a céu aberto vive e cresce na favela. Rio de Janeiro, 2012.

[Online:

http://envolverde.cartacapital.com.br/museu-a-ceu-abertovive-e-cresce-na-favela/opened 22.04.2020].

MOUTINHO, M. (2016). From New Museology to Sociomuseology. In 24th General Conference of the International Council of Museums, Joint Meeting MINOM/CAMOC/ICOFOM (pp. 1-3). [online:

http://network.icom.museum/fileadmin/user upload/minisit es/camoc/PDF/Newsletters/Minom 02.pdf opened on 22.04.2020].

PATEL, G. (2018). Museums of Counternarratives and Resistance, Part 1: Brazilian Museums In Context. [Online: http://www.rioonwatch.org/?p=43196 opened 22.04.2020].

PATEL, G. (2018). Museums of Counternarratives and Resistance, Part 2: A New Kind of Museum \#MuseumWeek2018. [Online: http://www.rioonwatch.org/?p=43330 opened 22.04.2020].

PEREIRA, M. R. N. (2018). Museologia decolonial: os pontos de memória e a insurgência do fazer museal. Lisboa (Doctoral dissertation)

PEREIRA LEITE, P. (2015). Sobre Ecomuseus, ecomuseologia e museus comunitários Roteiro para programa "Encontros com 0 Património da TSF". Portugal. [Online: https://informalmuseology.wordpress.com/informal- 
museology-studies/14-ecomuseus-e-museologiasocial/sobre-ecomuseus-ecomuseologia-e-museuscomunitarios/\# ftn2, opened 22.04.2020].

SILVA, C. R. R. D. (2007). Maré: a invenção de um bairro (Doctoral dissertation).Online:

http://bibliotecadigital.fgv.br/dspace/bitstream/handle/1043 8/2122/CPDOC2006ClaudiaRoseRibeirodaSilva.pdf?sequence =1\&isAllowed=y opened 22.04.2020]

SILVA, C.R.R. (2017). The Maré Museum. Come and learn our history. Permanent Exhibit. The Times Of Maré. Fight, Restistance, Memory. Translations: Katie de Araujo. Rio de Janeiro.

SILVA, C. R. R. (2012). Caminhos para a sustentabilidade dos museus na cidade. Um estudo de caso na RMRJ. Niteroi

SUPPIA, A., \& SCARABELLO, M. (2014). As reformas do Rio de Janeiro no início do século XX. Cidade é transformada para responder aos apelos do mundo que se moderniza. [Online: http://pre.univesp.br/as-reformas-do-rio-de-janeiro-noinicio-do-seculo-xx\#.W306c-gzYak opened 22.04.2020].

\section{Official documents:}

DECLARATION OF QUEBEC-Basic Principles of a New Museology 1984. Cadernos de Sociomuseologia, (38).

LACOUTURE, F. (1984). Declaratoria de Oaxtepec 1984: Ecomuseos, territorio, patrimonio y comunidad. Mesa Redonda de Oaxtepec. Oaxtepec, México. [Online: http://www.ibermuseus.org/wpcontent/uploads/2014/07/declaracao-de-oaxtepec.pdf opened on 22.04.2020]

NASCIMENTO Junior, J., Trampe, A., \& PA, D. S. (2012). Mesa redonda sobre la importancia y el desarrollo de los museos en el mundo contemporáneo: Mesa Redonda de Santiago de Chile, 1972. Instituto Brasileiro de Museus-IBRAM, Ministerio do Cultura, Ibermuseos. Brasilia.MINOM, M. (2010).

\section{Secundary Sources:}


Cadernos de Sociomuseologia. 2020. vol. 60. no 16

RAMALHO, S. WHO KILLED MARIELLE FRANCO? The intercept. 18.01.2019.

[Online:

https://theintercept.com/2019/01/17/marielle-franco-brazilassassination-suspect opened 22.04.2020]

Official Homepages of the Museums:

Homepage Museu de Favela. [Online:

https://www.museudefavela.org/opened 22.04.2020]

Homepage Museu da Maré. [Online:

http://www.museudaMaré.org.br/ opened 22.04.2020] 